\title{
Primary Education as a Foundation for Qualitative Higher Education in Nigeria
}

\author{
Comfort R. Etor ${ }^{1}$, Usen F. Mbon ${ }^{1} \&$ Ekpenyong E. Ekanem ${ }^{1}$ \\ ${ }^{1}$ Department of Educational Administration and Planning, University of Calabar, Calabar, Nigeria \\ Correspondence: Comfort R. Etor, Department of Educational Administration and Planning, University of \\ Calabar, Calabar, Nigeria. E-mail: mails4anietor@yahoo.com
}

Received: February 11, 2013

Accepted: March 21, 2013 Online Published: May 2, 2013

doi:10.5539/jel.v2n2p155

URL: http://dx.doi.org/10.5539/jel.v2n2p155

\begin{abstract}
Primary education is universally accepted as the foundation laying level of education in all nations of the world. It provides the mini-structural framework on which the quality of other levels of education is anchored. It is on this premise that this paper examines the pertinent issues that, if properly addressed would recapture and refocus policies in Nigeria for qualitative education at the secondary and tertiary levels. These issues include: A deliberate and conscious effort at achieving the goals of primary education in Nigeria, Addressing the perennial problems of teachers and teaching in primary schools and the management of primary education in general, Dealing with the virus of examination malpractices at the level of primary education and its effect on higher education. In the light of these and other issues adversely affecting the quality of products of education, this paper recommends, among others that the implementation of national policy in primary education by states and private institutions should be closely monitored to ensure uniformity in quality output from the nations primary schools. All primary schools in Nigeria, irrespective of where they are located, should be given a face lift with modern infrastructures in terms of building for administration, classrooms, introductory technology workshops, library, equipment and all relevant instructional materials to ensure effective teaching and learning.
\end{abstract}

Keywords: primary education, foundation, qualitative, higher education

\section{Introduction}

Education as a development agent, is valued by all nations of the world because it has brought total liberation to man. It has transformed man from ignorance and misery to knowledge and happiness. It has made man useful to himself, his generation and beyond. As rightly observed by Umoh (2006), education helps the individual to develop physically, mentally, morally, spiritually, and emotionally by providing suitable environment, teaching him new knowledge, attitudes and skills that will enable him to be useful to himself and his society. Education at this level strengthens the learner's feet to climb the educational ladder to the zenith of academic attainment if a good foundation is laid. The Federal Republic of Nigeria (2004), states that primary education refers to education given to children aged 6 to 11 plus in primary schools and that the primary level is the key to the success or failure of the whole system since the rest of the education system is built upon it. This statement confirms the fact that the primary level of education is most crucial to the success of other levels, hence the need for the stakeholders to do everything possible to lay a solid foundation for its sustainability.

For primary education to be the bedrock of educational system, Umoh (2006), maintains that it must bring to the learners elementary and general knowledge of science, by teaching them to use and operate scientific objects and gadgets so that they may be conversant with such foundational knowledge as they advance to other levels. In other to give the primary school (education) the focus FRN (2004) enumerated the goals of this level as to:

a. Inculcate permanent literacy and numeracy, and ability of communicate effectively;

b. Lay a sound basis for scientific and reflective thinking;

c. Give citizenship education as a basis for effective participation in and contribution to the life of the society.

d. Mould the character and develop sound attitude and morals in the child.

e. Develop in the child ability to adapt to the child's changing environment. 
f. Give the child opportunities for developing manipulative skills that will enable the child to function effectively in the society within the limits of the child's capacity.

g. Provide the child with basic tools for further educational advancement, including preparation for trades and craft of the locality.

The lunching of the Universal Basic Education (UBE) programme was the Federal Government effort to salvage the primary education system which is the foundation stone of other educational levels and infact, the corner stone of national development (Okpala, 2007). This confirms the submission by the present authors that primary education is the foundation for qualitative higher education in Nigeria. This is because it is the primary education graduates that gain admission into secondary education and later proceed to higher education. In this regard, the quality of output from primary education will definitely produce future professionals, such as technologists, engineers, educationists, lawyers, some of whom will become lecturers in higher education to teach students whose educational foundation is from the same primary education system. The term "qualitative" is used to portray the expected better output from higher education based on the desired good foundation laid at the primary education level.

As pointed out by Ijeoma (2004), Adedeji (2004), Onyeagba (2006), Saidu (2008), and Sen (2010), primary education is the foundation for a child's learning on which every other level of learning depends. In the light of these objectives, this paper examines how the primary school may be seen and rightly recognized as foundation of education in the society. Furthermore, Olaniyan \& Obadara (2008), submit that apart from the home as the first agent of socialization, primary school is the first that introduces formal education or literacy to the children. In other words, primary school education is a foundation upon which all other levels of education are built. Armstrong (2008) affirms that certainly, primary and secondary educations are both important elements of the sector, not least because they feed directly the quality of higher levels of education.

\subsection{Achieving the Goals of Primary Education}

The stated goals are attainable hence the Federal Republic of Nigeria (2004) on education states that these goals must be pursued through making primary education tuition free, universal and compulsory, implementing the curriculum; providing educational services, using practical, exploratory and experimental methods of teaching, using the language of the environment for the first three years as a medium of instruction; making the teacher-pupil ratio 1:35; promoting pupils from one class to another based on continuous assessment; discouraging the incidence of drop out at this level; integrating information and communication technology (ICT) into education in Nigeria; proving basic infrastructure and training of teachers for the realization of these goals at the primary school level, etc. These proposals on the one hand, simply present the functions expected of government or relevant government functionaries charged with the responsibility of management of schools, provision of infrastructure, equipment and instructional facilities. On the other hand, present the functions expected of teachers in laying the foundation for quality output in primary schools. These are considered as follows:

\subsection{Making Primary Education Tuition Free, Universal and Compulsory}

For over five decades, the Nigerian government has been advocating universal, free and compulsory education for the citizenry. The Universal Primary Education was launched in the Western region on January $17^{\text {th }} 1955$. In 1957, the scheme was launched in the East. The scheme was reintroduced by Obasanjo's Administration in 1976 with an enrolment of 475,760 pupils in primary schools. The Universal Primary Education scheme once again failed because of lack of adequate appraisal of the resources required for its implementation.

In the wake of realization of the importance of education as the basic tool of the Nigerian child for all round development, Nigeria launched the Universal Basic Education scheme on $30^{\text {th }}$ September, 1999. Every Nigerian child, it was envisaged would be entitled to basic education up to the junior secondary level. The education would be free, universal and compulsory for all children between the primary and junior secondary schools (Alabi, 2001).

\subsection{Implementing the Curriculum}

The prescribed curriculum for the primary schools, according to FRN (2004) include languages, mathematics, sciences, physical education, religious knowledge, agricultural science, economics, social studies, citizenship education, culture and creative arts, and computer education. For laying the solid foundation at the primary schools, government offered to provide the following educational services (i) Library services (ii) Basic health scheme (iii) Counseling services; educational resource centre and specialist teachers of particular subjects such as mathematics, science, physical education, language arts, music, fine arts and home economics. When the 
government does this in totality, the foundation of education will be concretized.

\section{Integrating Information and Communication Technology into the School Curriculum}

This is a welcome idea in Nigeria, especially at the primary school level as the world is constantly changing. This is because our nation is advancing scientifically and technologically, hence the need to introduce information and communication technology into the first level in education sector so that the entire educational system can have a dependable foundation. Johnson (2007) defines information as data that has been processed, analyzed, interpreted and meaningful to the recipient of the message. He also defines communication as a source of message and extension of imagination in latent form to assist production, perception and understanding of message.

It is of great importance for primary school children to be able to define what information is needed, know how and where to obtain information, understand the meaning of the information received and can act appropriately based on the information received. They need to be able to use the telephone, television, computer, etc. according to Uya (2000), children should know the meaning, history and uses of computer, computer system concept, and introduction to Ms-Dos, flash drives, programming, windows and computer rhymes. This will widen their knowledge as well as enable them to compete favourably with their counterparts in other parts of the world. This knowledge will help in laying a solid foundation in the primary schools.

Amadi (2007) outlines the importance of ICT to include giving learners the opportunity to apply and develop their ICT capability through the use of ICT tools to support their learning in most subjects, enabling pupils to use these technologies to design, deliver, select, administer and extend learning or communicate with experts, colleagues, peers both in and outside the classrooms. She confirmed that in this age of computers, learners have to understand the language of computing in order to carry out basic operations such as processing, checking information through surfing the computer to visit websites, sending and receiving information, storing and retrieving data, buying and selling, playing games, music and a host of other activities that are now available. But the problem facing the system is poor funding, hence ICT through introduced at this level, is at theory stage with no computers for practical. If the foundation must be laid properly, each school must be provided with computers for effective teaching and learning of the basics as outlined by Uya (2000).

However, there is evidence that the use of introductory technology alone does not guarantee better education. In Cuban's 1999-2000 study of Silicon Valley Schools, there was evidence that ten percent of the teachers used computers to teach, at least, once a week, but there was no evidence that information technologies increased student's academic achievement. He concluded that most investment in computers in the schools provide very poor returns. This is not because the use of computers are no more necessary as an instructional aid, but according to Cuban's findings nearly 90 percent of elementary and secondary school teachers still give lectures the old fashioned way, hence most computers in schools were returned to laboratories and used primarily for internet searchers and word processing.

\subsection{Primary Education as the Foundation of Education}

A house that has a shaky foundation will eventually collapse sooner or later. This is why it is advisable to employ the services of experts when one is set to build a house. In laying an enduring foundation for the entire education sector to build on, the providers of primary education should:

a. Lay the foundation in quality of teachers

b. Lay the foundation in quality of instructional materials/facilities

c. Lay the foundation in proper funding

d. Lay the foundation in quality output from primary schools

These are discussed below:

\subsubsection{Laying the Foundation in Quality of Teachers}

The teacher is the facilitator of learning. Without the teacher, most of the goals and aims of education cannot be achieved. The teacher holds the key to learners' educational attainment; if he can use the key effectively, the needed foundation will be laid in the primary level hence the need for him to be properly trained. The FRN (2004), recognizes this fact and emphasizes that teacher education shall continue to be given major emphasis, since no education system may rise above the quality of its teachers. Presently, the training of teachers for this level of education is done at the colleges of education, National Teachers' Institute, Institute of Education and Faculties of Education in Universities and School of Education in Universities of Technology. This is because the government has phased out teachers with Grade Two Certificate (TCII), and pegged minimum qualification for 
teaching in the primary school at Nigeria Certificate in Education (NCE). These institutions that are mandated to train teachers for the primary schools should endeavour to enrich their programmes so as to equip these teachers for better foundation laying in our children. Competent teachers should be employed to train these teachers, and students without the required entry qualification should not be admitted in the teacher training programmes. The programmes should be reviewed from time to time to suit the changes in the educational system due to technological and scientific changes in the society. At the end of the programme, only the competent teachers should be sent into the system, because it is only this set of teachers that can lay a solid foundation in the primary school.

Nakpodia (2001) also points out that teachers that are already serving should be retrained in order to make them functional in their jobs. This could be done through in-service education programmes or courses which include workshops, seminars, conferences, induction or orientation programmes, part time or sandwich courses and effective supervision by the bodies concerned. Effective supervision can go a long way in helping the teachers in our primary schools to lay solid foundation for other levels to build on. Accordingly, Chike Okoli (2006) enumerates teacher improvement purposes to include:

a. Ensuring that teachers do their assigned work effectively.

b. Ensuring new teachers receive training to enable them function effectively on the job.

c. Providing professional information to teachers

d. Guiding teachers to sources of instructional materials

e. Providing technical assistance to teachers, e.g preparation and use of teaching aid.

f. Ensuring that discipline is maintained in the classroom.

g. Maintaining high morale among the teachers.

h. Suggesting ways of improving teacher's performance.

i. Providing an opportunity to discover teachers with special abilities or qualities.

Any teacher that is so guided should be able to lay an enduring foundation for Nigeria's Educational System. In the foundation laying, the teacher plays various roles. Chike-Okoli (2006) states that the teacher that must improve instruction and lay a solid foundation has to do so by:

a. Planning his lesson, developing sound teaching principles and techniques.

b. Employing all possible teaching resources, providing appropriate and suitable learning conditions.

c. Helping the children to develop the desired skills, attitudes and competence

d. Supervising children's performance

e. Helping pupils to identify and providing conducive atmosphere in which they will love to work.

f. Creating challenging activities for learners to think and providing various learning experiences to cater for individual difference among the learners.

g. Acquiring a good understanding about his learner's maturational and intellectual levels so that he can choose appropriate content and methodology for instruction.

h. Keeping accurate records of work and performance of the students, giving exercises, making assignments, evaluating learners, checking their notebooks and exercise books and encouraging them to do private reading and making good use of the library (if available).

Dewey cited in Neill (2005) has been presented as the modern father of experiential education. He was concerned with why so many students hate school and the need for an educator to take into account the unique difference between each student as a way of tackling the problem. He contended that even when a standard curriculum is presented using established pedagogical methods each student will have a different quality of experience. To this end, teaching and curriculum must be designed in ways that allow for such individual differences. Dewey therefore proposed that education should be designed on the basis of a theory of experience with a focus on continuity and interaction. On continuity Dewey argued that we learn something from every experience, whether positive or negative and one's accumulated learned experiences influence the nature of ones future experiences. In other words, every experience in some way influences all potential future experiences for an individual. Continuity refers to the idea that each experience is stored and carried on into the future whether one likes it or not. 
On the aspect of interaction, Dewey submits the hypothesis that your current experience can be understood as a function of your past (stored) experiences which interacting with the present situation, create an individual's experience. He therefore contended that the teacher with good insight into the effects of past experiences with students bring with them better insight that will enable the teacher to provide quality of education which is relevant and meaningful for the students.

\subsubsection{Laying Foundation in Quality of Instructional Materials/Facilities}

The instructional materials and facilities are of great importance in the school system. Without them no meaningful learning can take place. For teaching, these materials should be provided - chalkboard, chalk, maps, globes, textbooks, magazines, chairs and desks, musical instrument, cupboards, school diary and register, continuous assessment, record books, charts, etc. others include school facilities such as buildings, pipe borne water, good lightning, television, video machine and tape recorder.

Similarly, Umoh (2006) maintains that the learners must be made familiar with radio, television, kerosene and gas cookers, scientific toys, instrument and machines. The learner must be allowed to use, touch, feel and play with them. He contends that, the construction of some of these instruments, where possible, by the teachers is to acquaint them with their structural components, even if the materials are improvised is an important part of science education in the primary school. For any teacher to perform the above functions judiciously in the primary school, he or she must not only be well trained but must be adequately motivated for the job. But this has not always been the case with teachers in our public primary schools, hence the generally observed nonchalant attitudes to work by teachers, resulting in ill-equipped children or poor foundation laying in children.

It therefore means that teachers are left out in the provision of instructional materials for effective foundation laying in the primary school. The school should provide the funds required for the improvisation of the relevant instructional materials for effective foundation laying in the primary schools. Some of the improvised materials can be supplied by the learners through their parents and the Parents Teachers' Association (PTA). Since government alone may not provide all the instructional materials needed for effective teaching and learning in our primary schools, where possible, it should be a joint venture between the parents and the relevant arm(s) of government concerned. The same approach may be necessary for the provision and maintenance of school structural facilities.

\subsubsection{Laying the Foundation in Proper Funding}

The Universal Primary Education (UPE) introduced in 1955 by the government of Western Region and in 1957 by the government of Eastern Region collapsed because of poor funding. In 1976, the federal government of Nigeria launched the Universal Primary Education which also failed due to lack of proper planning and funding. Accordingly, Onwueme (2001), notes that funding of education in Nigeria has been problematic over the years. He maintains that funding of primary education in particular should be handled by the three tiers of government. Accordingly, Onwueme (2001), report that:

a. Federal Government should be responsible for the provision of building and furniture, teachers' salaries and allowances and payment for the teacher-training programme.

b. State government should be responsible for the provision of equipment and libraries.

c. Local government should assume responsibility for non-teaching staff salaries, textbooks and maintenance of buildings

d. Parents should provide writing material and clothing for their children. Furthermore, Decree 31 of 1988 which established the Primary Education Commission offered the formula for funding of primary education as follows: Local Government $80 \%$, State Government 30\%, Federal government $20 \%$ while decree (3) of January 1999 made $100 \%$ funding of primary school the responsibility of local government councils. According to him, the recent revision of allocation formula whereby $41 \%, 36 \%$ and $23 \%$ allocated to the Federal, State and Local Governments have not been received by all concerned.

Fafunwa (2001) maintains that the Universal Basic Education covers non-literate Nigerians who make up $45 \%$ of our population in addition to all children of school age which represents another $20 \%$ of the population making a total of about $70 \%$ of Nigerian's population. He believes that $70 \%$ of education budget should be allocated to this level of education, because according to him, a system that neglects primary education, which is the very foundation of the entire educational system will not have good secondary or good university education, and neither its economy, nor its people will progress, and as a result poverty, ignorance and disease will envelop the people. However, the funding of UBE Programme in Nigeria has been enhanced in recent times as pointed out by Ekwere, Agunwena \& Okodoko (2008) that foreign governmental and non-governmental bodies are also 
rendering some forms of financial assistance. These bodies are the World Bank, United Nations Educational, Scientific Cultural Organizations (UNESCO) and United Nations International Children Emergency Fund (UNICEF).

\subsubsection{Laying Foundation in Quality of Output from Primary Schools}

The success of the entire educational system in Nigeria depends greatly on the output from the primary schools. By quality of output, it means the quality of the child or children processed from our public primary schools after six to eight years of schooling. This concern was expressed by Okoro (2005) by posing the following questions what emerges from the learner who has acquired this level of education? What are the expectations? What can the person (child) do? What can he not do? What problem can he/she solve for self, family and community? What problem is beyond the scope of the education the person has acquired? A careful study of our primary school system, its functioning and output would enable us provide objective answers to the above questions. But can we, on its face validity assert that there is anything like quality of output in our public primary school? Whatever the case, what are the expectations?

The Federal Republic of Nigeria (2004) spells out the goals of what the learners are expected to do at the end of acquiring this level of education to include ability to communicate and think effectively, ability to think scientifically, reflectively, and acquiring permanent literacy and numeracy. Can we candidly say that such foundations have been laid in our children in primary schools? Can a primary school child confidently express himself orally or in writing as a proof of good foundation laying in schools? What really are the problems? Actually, generally speaking, these children are unable to acquire the expected skills because of so many factors that militate against the effective functioning of our public primary schools. These include lack of commitment to qualitative education by all the stakeholders in terms of appointment and training of qualified teachers as administrators of primary schools, recruitment of qualified teachers, motivation of teachers, and regular payment of teachers' salaries. To this end, all the stakeholders must play their roles creditably. The three tiers of government must provide the necessary infrastructure, equipment and relevant instructional materials for effective teaching and learning in the primary schools. The recruitment and selection of teachers for primary school should be based on proven ability and interest in the education of the child and requisite entry qualifications into the teaching profession. Serving teachers should be sufficiently motivated so as to take their teaching assignment seriously.

Parents are expected to play their roles by providing learning materials and proper upkeep maintenance for their children in schools. They should cooperate and collaborate with teachers to ensure that the child does his/her homework, studies at home after school, and report abnormal behavior to the teacher for academic counseling and guidance at school. Teachers and parents should encourage children to learn instead of helping them to cheat in examinations. Teachers should concentrate all their efforts on teaching during school hours than reserving such important lessons for private lessons for which parents are made to pay compulsorily.

The headmaster/headmistress, school inspectors/supervisors should do their work effectively by ensuring that proper and periodic supervision of teachers is carried out at least twice in a school term to ensure improved performance by teachers. There should be prompt and regular payment of teachers' salaries and allowances as well as other incentives to boost their morale at work. It is the opinion of these authors that if these measures are judiciously adopted, the teachers are bound to take laying solid foundation in the education of our children in primary schools more seriously, and that expectation is achievable.

\section{Problems of Foundation Laying of Primary Schools}

From the discussions above, it is evident that problems abound in primary education in Nigeria. As pointed out by Adesina and Ajayi (2006), the problems in primary education in Nigeria include inadequate funding, inadequate facilities/learning materials, lack of motivation for teachers, inconsistencies in government policies, and inadequate schools supervision by government officials. Each of these problems have sub problems for example, can we justifiably say that the so-called inadequate funding has been judiciously utilized for the management of our primary schools? This is a problem because where there are urgent academic needs and the funds are not readily available for use, the school business activities are hampered and the administrator and teachers are frustrated.

Alani (2005) contends that the problems of public primary schools are inadequate physical, material, and human resources needed to give qualitative education. He lamented that this has remained a perennial problem arising from the age-long neglect of the funding of education. A case of neglect of primary schools where our Nigerian elites had their initial education was reported by Ubani (2007) in the House of Representative contract scam. The amount of money spent in the renovation of magnificent residence of the speaker could have been used to 
rebuild a thousand of dilapidated primary school blocks across the country, like the one at the Holy Cross School, Ikire, where the former speaker had her primary education (The Punch Newspaper, August 24, 2007). In some cases when the government manages to erect one classroom block out of four buildings required to accommodate the pupils, the remaining children are cramped into the same building, thus making effective teaching and learning impossible.

The persistent outcry on the problems of primary education in Nigeria tends to raise the question of whose responsibility it is to manage this foundation laying level of education. Emetaron (2005), contends that although primary education is a constitutional responsibility of local government, the sector has consistently remained an "orphan" which explains its piteous state of affairs. This is a serious matter which should be carefully addressed by all stakeholders in the education sub-sector. Oladipo (2005), has however, lamented that efforts made so far to make education qualitative and functional have not yielded desirable results in Nigeria due to socio-cultural and political diversity of the nation, hence, the observed variations in the implementation of the national policy on education. If education is the right of every Nigerian child and adult, efforts should be made to remove every form of socio-cultural and political barriers against the successful implementation of primary education policy objectives in Nigeria.

Teaching for foundation laying in primary education requires quality of teachers and in adequate quantity in all primary schools in the country. Anything short of this, result in poor quality of output and serious fall in academic standards, and a failure of the Universal Basic Education (UBE) in the country. Omoregie (2005) submits that during the launching of Universal Basic Education (UBE) in Sokoto in 1999, the President, Chief Olusegun Obasanjo blamed the fallen standard of education on the acute shortage of qualified teachers in primary school. If this is a true report, then the problem of acute shortage of qualified teachers in primary school teachers must be addressed. This may border on teacher motivation and retention, as some talented teachers may have been frustrated out of the system due to poor and irregular payment of salary, low status of primary school teachers as perceived by parents and the public and so on.

Another problem that tends to affect good foundation laying in our primary school is the number of subjects taught by each teacher. Oladipo (2005), in his study on primary education policy implementation (the Nigeria experience), notes with dismay, that there are 14 subjects on the primary school time-table. The curriculum is overloaded resulting in superficial teaching by the teachers. He submits that teachers agreed that not all the subjects on the time table were taught. The teacher also gave reasons for their poor performance to include shortage of teachers, lack of space, equipment, interest/commitment on the part of most teachers, and too many subjects in his class. This is why a teacher with poor foundation in mathematics and elementary science will definitely lay poor foundation in children in the elementary science at the primary school level. If that anomaly is not corrected by good mathematics and integrated science teachers at the Junior Secondary School level, then the future of our children in this age of science and technology is in jeopardy.

Examination malpractice in Nigeria schools is currently a big business involving syndicate and stakeholders in the school at all levels. Unfortunately, this started as a proverbial small mustard seed, planted by teachers with the support of some parents at the primary school level. Notably, some teachers who do not teach effectively and cover their scheme of work do resort to helping pupils to cheat in internal and external examinations. By so doing, a wrong foundation is laid in the children. As they pass common entrance examinations to secondary schools, the same virus of examination malpractice is nurtured and they cheat from class work to external qualifying examinations like West African Examination Council (NECO), and the Joint Admission and Matriculation Board (JAMB). Table 1 below shows the 2006 Examination malpractice rating of each state of the federation as contained in 2007 Exam Ethics Report, reported in the Punch Newspaper, October 5, 2007, page 37. 
Table 1. 2006 Exam Malpractices Rating of States in Nigeria

\begin{tabular}{|c|c|c|c|c|c|}
\hline $\mathbf{S} / \mathbf{N}$ & State & $\begin{array}{l}\text { Total No. of } \\
\text { Candidates } \\
\text { Involved }\end{array}$ & $\begin{array}{l}\text { Total No. of } \\
\text { Candidates } \\
\text { Sat }\end{array}$ & $\begin{array}{l}\text { Examination } \\
\text { Malpractice } \\
\text { Index } 2006\end{array}$ & $\begin{array}{l}\text { Exam Malpractice } \\
\text { Ranking (Rating) }\end{array}$ \\
\hline 1. & Bornu & 3416 & 19790 & 17.26 & $1^{\text {st }}(37)$ \\
\hline 2. & Abia & 4085 & 27034 & 15.11 & $2^{\text {nd }}(36)$ \\
\hline 3. & Enugu & 5387 & 38215 & 14.10 & $3^{\text {rd }}(35)$ \\
\hline 4. & Imo & 3867 & 31366 & 12.33 & $4^{\text {th }}(34)$ \\
\hline 5. & Bayelsa & 1221 & 10090 & 12.10 & $5^{\text {th }}(33)$ \\
\hline 6. & Lagos & 18335 & 153419 & 11.95 & $6^{\text {th }}(32)$ \\
\hline 7. & Ebonyi & 3274 & 29922 & 10.94 & $7^{\text {th }}(31)$ \\
\hline 8. & Cross River & 2887 & 28779 & 10.03 & $8^{\text {th }}(20)$ \\
\hline 9. & Rivers & 7368 & 73612 & 10.01 & $9^{\text {th }}(29)$ \\
\hline 10 & Edo & 5330 & 64463 & 8.27 & $10^{\text {th }}(28)$ \\
\hline 11. & Benue & 3575 & 4347 & 8.22 & $11^{\text {th }}(27)$ \\
\hline 12. & Nasarawa & 1811 & 27704 & 6.54 & $12^{\text {th }}(26)$ \\
\hline 13. & Kogi & 2994 & 47022 & 6.54 & $12^{\text {th }}(26)$ \\
\hline 14. & Ondo & 1998 & 31550 & 6.33 & $14^{\text {th }}(24)$ \\
\hline 15. & Taraba & 785 & 14009 & 5.60 & $15^{\text {th }}(23)$ \\
\hline 16. & Osun & 2036 & 37255 & 5.47 & $16^{\text {th }}(22)$ \\
\hline 17. & Kaduna & 2371 & 45526 & 5.21 & $17^{\text {th }}(21)$ \\
\hline 18. & Adamawa & 1032 & 24784 & 4.16 & $18^{\text {th }}(20)$ \\
\hline 19. & Ekiti & 743 & 18663 & 3.98 & $19^{\text {th }}(19)$ \\
\hline 20. & Kwara & 854 & 21945 & 3.89 & $20^{\text {th }}(18)$ \\
\hline 21. & Anambra & 1005 & 27325 & 3.68 & $21^{\text {st }}(17)$ \\
\hline 22. & Akwa Ibom & 1631 & 45055 & 3.62 & $22^{\text {nd }}(16)$ \\
\hline 23. & Ogun & 1414 & 43167 & 3.28 & $24^{\text {th }}(15)$ \\
\hline 24. & Yobe & 369 & 11409 & 3.23 & $24^{\text {th }}(14)$ \\
\hline 25. & Jigawa & 220 & 7698 & 2.88 & $25^{\text {th }}(13)$ \\
\hline 26. & Oyо & 1456 & 54454 & 2.68 & $27^{\text {th }}(12)$ \\
\hline 27. & Delta & 617 & 23223 & 2.66 & $27^{\text {th }}(11)$ \\
\hline 28. & Plataeu & 692 & 31265 & 2.21 & $28^{\text {th }}(10)$ \\
\hline 29. & Kano & 628 & 29129 & 2.16 & $29^{\text {th }}(9)$ \\
\hline 30. & Niger & 437 & 20741 & 2.11 & $30^{\text {th }}(8)$ \\
\hline 31 & Gombe & 140 & 6688 & 2.09 & $31^{\text {st }}(7)$ \\
\hline 32. & Sokoto & 273 & 13581 & 2.01 & $32^{\text {nd }}(6)$ \\
\hline 33. & Zamfara & 193 & 9910 & 1.95 & $33^{\text {rd }}(5)$ \\
\hline 34. & Bauchi & 164 & 8846 & 1.85 & $34^{\text {th }}(4)$ \\
\hline 35. & Katsina & 254 & 17538 & 1.45 & $35^{\text {th }}(3)$ \\
\hline 36. & Kebbi & 53 & 7593 & 0.70 & $36^{\text {th }}(2)$ \\
\hline \multirow[t]{2}{*}{37.} & Abuja & 24 & 8022 & 0.30 & $37^{\text {th }}(1)$ \\
\hline & Total & 82841 & 1154266 & 7.19 & \\
\hline
\end{tabular}

Note: Highest Examination Malpractice Rating $=37$

Lowest Exam Malpractice Rating $=1$

Source: The Punch News-Paper Friday October 5, 2007 p. 37. 
The report as captured by Olugbile (2007) indicates that Nigeria loss $\$ 107 \mathrm{~b}$ to exam malpractices in five years. Moreover, it added that examination malpractices have metamorphosed into organized crime controlled by syndicates with links in education ministries, examination boards, and educational institutions. Accordingly, supervisors, invigilators and examiners are now part of the syndicate rings extorting money from students in examination halls or prior to it. This is a death trap in our educational system that must be removed at all cost starting from the primary school level.

\section{Conclusion}

The output of our primary schools are the ones that are fed into our secondary schools, hence, the quality of foundation laid for learning of comprehension and understanding determine how they will perform in secondary and tertiary levels of education. This discussion on primary school as a foundation of education in Nigeria calls for urgent attention on the issues raised in this paper which portrays the state of the art in our primary schools. The quality of student admitted into higher education in Nigeria is generally observed as very poor. It is therefore expected that the concerns raised shall be passionately looked into by the stakeholders in the education sector with a view to ensuring that a solid foundation is truly laid at the primary school level as a way of ensuring technologically and scientifically oriented outputs for other levels of education in the country.

\section{Recommendations}

Primary education is the foundation on which all other levels of education are laid. Such foundation should therefore be strong, reliable and capable of withstanding all forms of pressure - atmospheric, socio-cultural, ethnic and economic pressures. In other words, the relevant providing agencies - governmental and private, should provide all it takes to lay the solid foundation expected at the primary school level of education in Nigeria. On this premise, it is therefore recommended that:

a. Government should ensure that the implementation of national policy on primary education by state owned and private institutions are closely monitored to ensure uniformity in quality of output from our nation's primary schools.

b. Funding for primary education should be shared among the Federal, States and Local Government on a reasonable ratio in their annual budgets for education.

c. All primary schools in Nigeria, irrespective of where they are located should be given a face-lift with modern infrastructure - Administrative building, classrooms, introductory technology workshops, library equipment and all relevant materials to ensure effective teaching and learning.

d. Teaching in primary schools should not be open to whoever wants to teach for a living. Only professionally trained, talented and well screened teachers should be employed to teach in primary schools.

e. A new salary structure for teachers should be implemented to enhance their job satisfaction and retention.

f. Only experienced primary school teachers should be assigned to teach and lay solid foundation in junior classes.

g. To check incidence of examination malpractices in primary schools, teachers should be made to teach effectively and cover their scheme of work sufficiently. Moreover, only teachers of proven integrity and good conduct should be assigned to supervise/invigilate internal and external examinations. Those caught in examination malpractices such as students, teachers, invigilators and supervisors should be made to face the existing law which should be activated.

\section{References}

Adesina, A. D. O., \& Ajayi A. A. (2006). Elementary Educational Programmes in Nigeria: Achievements, Problems and Challenges. Nigerian Journal of Curriculum Studies, 13(1), 34-44.

Alibi, A. T. (2001). Effective Management Strategies for a Free and Compulsory School System in Kwara State. Current Issues in Educational Management in Nigeria, 2(1), 24-37.

Alani, R. A. (2005). Deregulation of the Ownership and Management of Primary and Secondary Schools in Nigeria: Issues and Policy Options from Planners Perspective. Deregulation the Provision and Management of Education in Nigeria, 4(1), 40-47.

Amadi, M. N. (2007). Management and Integration of Information and Communication Technology in Distance Learning in Nigeria. Journal of Education Management, 6(1), 233-240.

Anukam, I. L. (2001). Investigating Factors Influencing Primary School Pupils Learning Achievement in Imo State. Current Issues in Educational Management in Nigeria, 3(1), 71-99. 
Armstrong, S. (2008). On higher education and development. Retrieved from http://www.eastasiaforum.org/2008/08/26/larry-summers-on-higher-education-and development

Chike-Okodi, A. (2006). A Supervision of Instruction and Accountability. In J. B. Babalola, A. O. Ayeni, S. O. Adedeji, \& A. A. A. Suleiman (Eds.), Educational Management: Thoughts and Practice. Ibadan: Codat Publications.

Cuban, L. (2003). Oversold and Underused: Computers in the Classroom. Retrieved from http://www.hup.harvard.edu/catalog.php?isbn=9780674011090\&content=reviews

Egwuasi, P. I., Ekwere, M. E., Azunwena, R. N., \& Okododo, D. (2008). The Universal Basic Education (UBE) and Sustainable Human Development in Nigeria. Nigeria Journal of Educational Administration and Planning, 8(2), 59-72.

Emataron, U. (2005). Deregulation in the Management of Primary Education in Nigeria: The Need for Legislation. NAEAP, 4(10), 312-317.

Fafunwa, A. B. (2001). Educational Management in Nigeria. Current Issues in Educational Management in Nigeria NAEAP, 2(1), 2-12.

Federal Republic of Nigeria. (2004). National Policy on Education. Yaba: NERDC.

Johnson, O. A. (2007). Enhancing Quality in Higher Education through Information and Communication technology in Nigeria. NAEAP, 506-572.

Nakpodia, E. D. (2001). The Role of Educational Administration in the Promotion of In-service Teacher Education for Primary School Teachers in Nigeria. NAEAP, 2(1), 377-396.

Neill, J. (2005). John Dewey, The modern father of experiential education. Retrieved from http://www.widerdom.com/experiential/ Experiential /Dewey.html

Okoro, O. (2006) Critical Analysis of Terms: School Products and Educational Outcome. In O. Okoro, \& N. O. Nwankpa (Eds.), Educational Outcome (pp. 23-35). Onitsha: Lincel Publishers.

Oladipo, S. A. (2005). Primary Education Policy Implementation: The Nigerian Experience. In Alani, R. A. (Eds.), Managing the Education System: A Book in Honour of Prof. O. E. M. Fagbamiye. Ilesha: Triumph Providential.

Olaniyan, D. A., \& Obadara, O. E. (2008). A critical review of management of primary Education in Nigeira. International Journal of Africa \& African American studies, VII(I). Retrieved from https//ojs.siver.edu/ojs/index.php/ijaaas/article/view

Olugbile, S. (2007). Examination Ethics Report (p. 37). The Punch Newspaper October.

Omoregie, E. D. (2005). Teachers Adequacy and Deregulation of the Education Sector: A Comparative Study of Public and private Secondary Schools in Edo State. NAEAP, 1(1), 148-152.

Onyeagba, J. (2006). Objectives of vocational education at primary, secondary and tertiary levels. In O. Okoro, \& N. O. Nwankpa (Eds.), Educational outcome (pp. 36-46). Onitsha: Lincel Publications.

Onwueme, M. S. (2001). Management of Free and Compulsory Education in Nigeria: Issues and Problems. Current Issues in Educational Management in Nigeria, 13-23.

Okpala, B. N. (2007). Maintenance Culture and the sustainability of the UBE programme in Nigeria. JORDE, $3(2), 115-122$.

Ubani, E. (2007). Contracts: We Have Nothing to Hide. Punch Newspaper, 9.

Umoh, G. G. (2006). Path to Quantitative Education: A Standard Book for Students, Teachers and Educational Administrators. Uyo: Inela Ventures and Publishers.

Uya, A. (2000). Computer for Nursery and Primary Schools. Calabar: CATS Publishers.

Saidu, S. (2008). Primary school education reforms for better foundation of education in Nigeria. Zaria educator, 3(1 \& 2). Retrieved from http://dspace.unijos.edu.ng/handle/10485/2042

Sen, A. (2010). Primary schooling in West Bengal. Prospects quarterly review of comparative education, 155(3), 311-320. http://dx.doi.org/10.1007/s11125-010-9164-4 